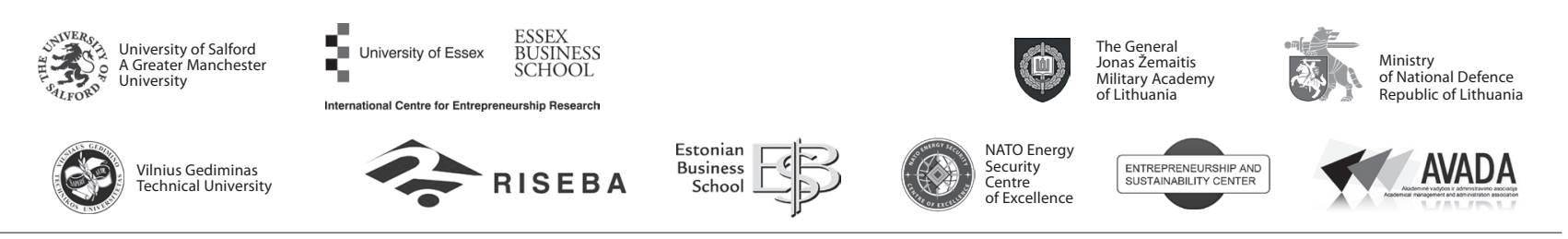

\author{
JOURNAL OF SECURITY AND SUSTAINABILITY ISSUES \\ ISSN 2029-7017 print/ISSN 2029-7025 online \\ 2018 March Volume 7 Number 3 \\ https://doi.org/10.9770/jssi.2018.7.3(12)
}

\title{
TOWARDS ENHANCED SAFETY: GOOD PRACTICES AND INFORMATION TECHNOLOGIES FOR PENAL SYSTEM
}

\author{
Elena A. Timofeeva \\ Samara Institute of Law of Federal Penitentiary Service of Russia, Samara, Russia; \\ Research Institute of the Federal Penitentiary Service of Russia, Moscow, Russia \\ E-mail: anna0474@mail.ru
}

Received 12 February 2017; accepted 24 November 2017

\begin{abstract}
In the modern socio-political reality, in the conditions of changing laws and reformation of the penal system, the economic optimization of activities of the establishments and bodies of the Federal Penitentiary Service of Russia and its employees becomes especially topical. The purpose of the article is to study implementation of the leading experience and innovational technologies into the activities of the penal system as a factor of economic optimization of financial and human resources. In the process of the research, the general and specific scientific methods were used. The author provides the examples of using innovational technologies by employees of the penal system in the process of execution of punishments: systems of electronic document turnover, program, and technical complex of automatized filing of special squad, video surveillance in the penal system establishments, etc. The successful execution of the tasks of the penal system and economic optimization of its activities will be stimulates by implementation of the experience of foreign penitentiary systems (preferable use of the cell-prison system, consideration of architectural peculiarities of prisons for saving human resources and security of an establishment, practice of functioning of private prisons, creation of the genetic data base, etc.). The result of the performed analysis is determination of basic professional requirements set to the employees of the penal system who implement innovations and the conditions that stimulate economic optimization of expenditures in the sphere of human and financial resources of the penal system.
\end{abstract}

Keywords: safety penal system, penitentiary system, innovational technologies, leading experience, employee, prison

Reference to this paper should be made as follows: Timofeeva, E.A. 2018. Towards enhanced safety: good practices and information technologies for penal system, Journal of Security and Sustainability Issues 7(3): 526-532.

https://doi.org/10.9770/jssi.2018.7.3(12)

JEL Classifications: K14, M15.

\section{Introduction}

The global experience of execution of punishments, which supposes deprivation of freedom, has formed over many centuries. As of now, in the penal system of Russia, which is the most important social institute that solves large-scale tasks of legal, economic, social, and psychological \& pedagogical character, the process of reformation is under way. The notions "penal system" and "penitentiary system" shall be viewed as synonyms, as in both cases we speak of public enforcement, expressed on implementation of penal punishments for persons deemed guilty in commission of crimes. The Concept of development of the penal system of the RF until 2020 (The Concept of development of the penal system of the RF until 2020) (hereinafter - the Concept) says 
that the penal system preserves features of the old penitentiary system, which is oriented at a different society. Unfortunately, it does not take into account the Russia's integration into the international legal field, the international standards of handling prisoners, and the existing leading penitentiary experience of foreign countries.

The Concept determines the main directions of the reform in the following way:

- increase of effectiveness of the work of penal establishments and bodies to the level of the European standards of handling prisoners and the needs of public development;

- reduction of repetition of offences, performed by the persons who completed sentence in the form of deprivation of freedom, by means of increase of social and psychological work in detention facilities and development of the system of post-penitentiary help to such persons;

- humanization of conditions for persons taken into custody and the persons serving sentences in the form of deprivation of freedom, increase of guarantees of observation of their rights and legal interests (Greetings... 2013).

The Concept, as a strategic document, emphasized the necessity for implementing innovational technologies and leading domestic and foreign experience into activities of employees during the work with convicts, organization of regime and security of the penal system. The term "leading experience" is treated as new, progressive forms and methods of work, practice-backed and scientifically substantiated system of organization and activities of services and branches of the Federal Penitentiary Service of the RF, the best examples of labor, etc., which are representative for a large number of branches of the the Federal Penitentiary Service of the RF. Implementation of the leading experience into activities of the country's penal system is one of the most important tasks in the process of further improvement of activities of the Federal Penitentiary Service of the RF, including economic ones. Among many problems faced by the Russia's penitentiary system, one of the most topical is the problem of economic optimization of financial and human resources of the penal system. The term "optimization" is treated as a certain choice out of all possible variants of using the resources - of the ones that provide the best results.

\subsection{Literature review}

The problems of innovative activities in the penal system were studied by numerous authors (Lesting 2018, Seijas 2017, Abeuov 2017, Grushin 2017, García-Ruiz et al. 2016). The theoretical and practical aspects of personnel management in innovational organizations are studied in the works of Deng (2017), Mironova et al. (2017), Vodenko et al. (2017), Danilina et al. (2016), Achkasova and Mazhnyk (2016).

The problem of involvement of convicts in labor within the system of reformation of the system of managing the industrial complex of the penal system was studied in the works of Rudy (2013), Timofeeva (2015), Zlakazova (2014), Luzgina (2017), Luhn et al. (2017).

\subsection{Establishing a research gap}

The previous studies do not allow for complex consideration of the problem and perspectives of realization of economic optimization of financial and human resources in activities of the Russia's penal system on the basis of using leading experience and innovational technologies. Also, the previous studies did not view the issues of professional requirements that are set to the employees of the penal system who implement innovations and the conditions that stimulate economic optimization of expenditures in the sphere of human and financial resources of the penal system. The author studied the rather-legal aspect and analyzes the existing domestic and leading foreign experience and using innovational technologies and equipment from the point of view of economic optimization of the penitentiary system's activities.

\subsection{Aim of the study}

In this context, our purpose is consideration of the issue of implementing the leading experience and innovational technologies, which should and has to stimulate the improvement of the Russia's penitentiary system, including in the sphere of economic optimization of its activities. 


\section{Methodology}

\subsection{Research methods}

In the process of the research, the general scientific (analysis, synthesis, comparison, and generalization) and specific scientific (rather-legal, etc.) methods were used, as well as sociological survey, methods of empirical and social analysis, secondary analysis of sociological data, collection and processing of information.

These methods allowed for complex study of the problems of modernization of the penitentiary system of Russia, conduct of comparative analysis of the leading experience of foreign countries, which is perspective for implementation into the Russian penitentiary practice, generalization and presentation of the most effective modern innovational technologies, aimed at economic optimization of activities of establishments and bodies of the penal system.

\subsection{Research basis}

The basis of the research includes scientific studies, publications of the Russian and foreign jurisprudents and economist who study various aspects of activities of the Russia's penitentiary system, and the laws in the sphere of the penal system.

\subsection{Research stages}

The problem was studied in two stages:

First stage: analysis of existing scientific literature on the topic of the research and of the laws in this sphere; determination of the problem, goal, and methods of the research.

Second stage: formulation of conclusions received in the course of analysis of scientific literature and laws, preparation of the publication.

\section{Results}

Let us view several examples of using the leading experience and innovational technologies in the Russia's penitentiary system from the point of view of the possibility of improvement of the penal system's functioning and, in particular, in the sphere of economic optimization of its activities. Starting from 1990's, the studies of the issues of regime and security of execution of punishment in the form of deprivation of liberty noted advantages of the cell-prison system for convicts, as compared to the Soviet corrective-labor system. However, prison, as a place of serving a sentence, is the least crowded form of penitentiary establishments in the Russia's penal system. The number of prisons in Russia accounts for $1 \%$ - only 8 establishments of all types of penitentiary establishments.

At that, prison is the main establishment for serving a sentence in the developed penitentiary systems of the world. Due to this, the cell-prison concept, as a developed positive leading experience in the conditions of reformation of the Russia's penal system, is very topical. During organization of the cell-prison system for convicts in the foreign countries, a lot of attention is paid to the issues of economic expedience of investing the state assets into the penitentiary institutions built according to a certain architectural type. From the point of view of certain penitentiary specialists, it is experience to use such architectural forms as "cross" or "star" during designing the Russian penitentiary establishments. These architectural forms ensure optimization of activities in the sphere of using human resources and security of the institution. Control over the convicts becomes simpler, as all posts are interconnected visually and remotely. An example of implementation of an architectural form is the new Kresty-2 detention facility. On the contrary, the architectural building in the form of "triangle" and "polygon" may hinder the effectiveness of activities of the prison employees. A positive - from the economic point of view - foreign experience of execution of punishment is the practice of private prisons. They are very effective in the justice systems of Austria, Brazil, Hungary, Norway, USA, France, Japan, etc. 
Let us note that the state is interested in effective functioning of the penitentiary system, which will result in successful resocialization of citizens, as it will stimulate the socio-economic stability of the society.

However, transition to market relations in economy complicated realization of requirements of the penal law on mandatory attraction of convicts to social labor required the change of the existing structure and forms of labor use of convicts. The share of production objects that worked in cooperation with the penal institutions or used the labor of convicts on the intermediary basis reduced. The highest number of problems that require quick solution has accumulated in the economic and managerial spheres (Vinogradov 2008). The director of the Federal Penitentiary Service of the RF Gennady Kornienko noted several years ago that it was necessary to study and use foreign experience on creation of private prisons. In particular, at one of the meetings, the director of the Federal Penitentiary Service of the RF noted that an interesting practice in the sphere of public-private partnership for construction of new pretrial detention facilities and prisons existed in England.

The advantages of private prisons for the state consist in the fact that they allow reducing the general financial load on the penitentiary system and increasing the quality of its functioning. The state saves assets on construction of prisons. Entrepreneurs invest money into equipping the production premises and production machines, select and train workforce for production. Instead, the state provides entrepreneurs with certain financial subsidies - reduction of tax load, etc. Private prisons are the most profitable business in the complex of prison industry. Thus, 20 corporations in 27 American states have circa 100,000 convicts in their establishments. The largest are the the Corrections Corporation of America (CCA) and Wackenhut, which control 75\% of this market. Private prisons receive certain assets from the state for each convict, regardless of a convict's costs. Entrepreneurs do not face such things and insurance for unemployment, strikes, vacations, etc. All persons involved in production are never late and work a full day. At that, certain researchers note the danger of possible corruption ties between the management of private prisons and judicial authorities (Luzgina, A. 2017). It may well be that each convict is seen by the prison administration as "future profit", and thus there may be corruption interaction with judges. Judges may make more judgments of guilt with larger terms of sentence. Thus, each additional year in a prison will bring additional profit. However, this is a debatable issue. We think that the flexible concept of public-private partnership in the sphere of execution of punishments, offered in foreign counties, needs to be studies for the purpose of possible implementation of its elements into the existing structure of the Russian penal system.

From the point of view of economic optimization of the penal system's activities, implementation of innovations in the systems of information provision is very interesting (Luhn et al. 2017). Special attention is paid to the possibilities of implementing the systems of information provision, based on using the integrated data bases with organization of quick access for employees directly from the work places, as well as system of CCTV, etc.

An example of implementation of experience of new methods of work with information is formation in the penal system of the integrated methodology of collection, processing, storing, and protection of information of the operative, reference, and statistical purpose - EDMS (electronic data management system). A computer innovation that entered the everyday professional activities of the penitentiary system's employees is electronic logs. Application of electronic logs in the work with convicts allows the employees to accumulate information and create databases which can be used by all interested parties during decision making for execution of punishments. Implementation of EDMS and electronic logs makes it unnecessary for employees to work only with paper carriers, which allows the system to save financial assets. Also, the positive results in saving the time of employees of the department of regime of pretrial detention facilities of the penal system comes from implementing into their service activities various computer technologies and programs. For example, implementation of a computer program, "Article 33" allows for optimal distribution of suspects, accused, and convicts in detention facilities and thus saving the time of employees and minimizing the errors caused by the human factor, during observation of the requirements of Article 33 of the Federal Law dated July 15, 1995, No. 103-FZ "Concerning the Detention of Persons Suspected and Accused of Committing Crimes". Application of videoconference with regional and supreme courts in the work of pretrial detention facilities of the penal system reduces the service load on judicial convoy of the suspects and accused and saves fuel for specialized 
vehicles. The automatized information support for events on prevention of offences and crimes of suspects and the accused is provided by the program and technical complex of the automatized filing of special squad (hereinafter - PTC AFSS). The PTC AFSS was accepted for operation in early 2000's and is now successfully used in a lot of establishments. The complex is an information \& search system that covers various aspects of activities of services that deal with accounting of convicts, suspects, and the accused. This function is important for the employees of the special squad, alert unit, and operation section. Thus, implementation of the PTC AFSS in detention facilities enabled creation of the automatized work place for the employees of the above departments of detention facilities and covering the information directions of these services that conduct special accounting. The PTC AFSS of detention facilities works around the clock in the network regime. The main peculiarities of the complex are simplicity and convenience in exploitation, scalability, the module principle of construction, openness for interaction with other systems and connection of external modules, compact and reliable storage of information, quick processing and provision of necessary information for the addressee. The library of standard accounting form with a possibility of forming the initial documents allows for quick and precise preparation of various documents. The achievement of the PTC AFSS is Photomaster module for processing of photographs for a special squad and Dactomaster module for working with fingerprints of convicts, suspects, and the accused.Implementation of videoanalysis (computer vision) into the system of CCTV in the establishments of the penal system allowed for optimization and simplification of the work of CCTV operators in the penal system's establishments. Due to this function, the CCTV function acquires a range of new useful qualities - integration with other modules of the system of the establishment's security. Along the local network of the establishment from the allowed spots it is possible to conduct monitoring of the incoming information from the system of control of access management on the object or to check the work of sensors on the protected perimeter. The function of videoanalysis allows tracking the work of CCTV cameras, checking the quality of video signal, and recognizing faces that are covered by the camera. A group of cameras allows tracking the movement of persons, finding stray objects, strange groups of people, etc.

A leading information and technical means of control over the convicts and their guard, applied abroad, is special signal sensors, which can be placed in cells and on collars of service dogs. As usage of service dogs in the Federal Penitentiary Service of the RF is very wide, the leading experience in this sphere of the Israeli colleagues is very interesting in Russia. Thus, the Israel Prison Service, known as Shabas, uses a special computer program that allows interpreting barking of service dogs during a break attempt or other forbidden action by convict (Timofeeva, 2015).

A method of increase of quality of providing the regime and conduct of control over the convicts that serve a sentence in detention facilities and the persons in detention is application of the modern systems of biometric identification of the personality in service activities of detention establishments and pretrial detention facilities.

A large potential for saving human and material resources is posed by using the data base of biological material in the service activities. Each year, 300,000 people are freed from the detention facilities. According to the official statistics, the highest level of repeated offences is observed among ex-convicts, for they perform every fifth crime. The convicts DNA data base helps finding hard core criminals and solving crimes. Besides, this measure will help to prevent prison breaks and identity theft. In Russia, the system of DNA registration is successfully used in dozens of laboratories of forensic and medico-legal services. Equipping the forensic departments with the automatized systems of DNA analysis created preconditions for implementation of this program. This required adoption of the normative and legal acts that regulate the corresponding activities. According to the requirements of the Government of the RF dated October 11, 2011 No. 828 "On adoption of the Provision on the order of conducting the mandatory state genome registration of persons who are convicted and serve sentences in the form of deprivation of liberty", the genome information is to be stored until the death of the convict, and if his fate is unknown, his genes are to be stored until his hypothetical age of 100. It should be noted that the timely registration of persons inclined to performing repeated offences by creating a data base of hard core criminals (including their genome registration) will be an effective measure of individual prevention. However, the issue of the mechanism of obtaining the samples from the persons subject to mandatory genome registration is not yet fully solved in Russia. At the same time, in other countries a convict (suspect) may be 
asked to provide a sample voluntarily, or a sample may be taken on the basis of the police order or court decision. In case of refusal to provide a sample, there could be: a) sentence; b) physical coercion to provide a sample; c) obtaining a sample from the item that contains biological (cell) material of this person. The possibility of implementation of the norms on intrdocution of the data base of genetic material in Russia is limited due to economic reasons. Thus, the expenditures of the UK for supporting the created data base of genetic material constituted GBP 4,290,500 in 2008-2009. Another direction of possible integration in the sphere of economic optimization of the leading foreign experience in the activities of the penal system at the modern stage is psychological and pedagogical direction. The world penitentiary practice shows that this direction is very diverse.

For the state and society, returning the persons who have made mistakes in the past but have returned into society as professional specialists to the society is very important. An example for the Russian penitentiary system is the aggression replacement training, which was developed for minors by A. Goldstein and B. Glick. This program was further developed in certain countries of Europe (Iceland, Denmark, Finland, Lithuania, and Turkey) and some American states. It views the possibilities of cognitive behavioral influence, which teaches a person to cope with aggressive behavior. Practical realization of this program was implemented in several detention facilities of the Federal Penitentiary Service of the RF ten years ago. For the penal system, the ART project started in 2006 within the cooperation between Norway and the Republic of Karelia. This approach, which is expressed in the program of modifying the behavior and technologies that were implemented in practice in socio-therapeutic establishments of the Netherlands, Denmark, and Germany by specialized therapeutic measures, is aimed at social help and provision of subsidies to convicts. These measures provide resocialization of convicts, including economic resocialization and preparing them for leaving the prison as specialists with various professional skills. A main trend in the work for resocialization of convicts in Germany is their professional training. Thus, professional education is organized in cooperation with prison administrations and federal committees on labor and free German trade unions.

It should be noted that an important condition of successful implementation of any innovation or leading experience is professional training of the penal system's employees. According to A.A. Rudy, "the system of departmental professional education should react to any changes in the organization of activities of establishments and bodies of the Federal Penitentiary Service of the RF and ensure training of specialists that are capable of performing service duties at the modern stage of development of the penal system. In the conditions of reformation, it is important to prepare the penal system's employees who possess the newest psychological and pedagogical methodologies and technologies of influencing the citizens' behavior in the conditions of isolation from society, skills of work with new telecommunication systems and modern technical means of custody and control. The training programs should be close to real conditions of service activities of the penal system's establishments and bodies" (Zlakazova, 2014).

\section{Conclusions}

Analysis of the described implementation of leading experience and innovational technologies into the penal system's activities led to formulation of a range of basic professional requirements set to employees:

- personalized attitude of employee to the innovation;

- possession of special professional skills (methodologies, strategies of modeling, etc.);

- interaction with other practical employees in the sphere of implementation of innovation (development of the social network of professional contacts).

It should be concluded that successful integration of various innovations and leading experience that lead to increase of effectiveness of the penal system's activities, including economic optimization of expenditures in the sphere of human and financial resources, will be stimulated by the following conditions:

- training and professional preparation of the penal system's employees;

- legal and methodological provision of this process;

- thorough selection of employees for implementation of innovational technologies, programs, leading experience, etc.; 
- monitoring (control) of the intermediary stage of this work;

- analysis of the obtained results.

It is possible that many of the above will seem ambiguous and debatable for readers. Still, conducting scientific research with analysis of implementation of leading experience and innovational technologies into the penal system's activities is vital for increasing its economic effectiveness.

\section{References}

Abeuov, D. 2017. On the need to include representatives of religion in the activities of institutions of the penal system, Journal of Advanced Research in Law and Economics 8(5): 1411-1415.

Achkasova, O. V., Mazhnyk, L.O. 2016. Innovations in personnel management of domestic enterprises: Trends and specificity, Actual Problems of Economics 176(2): 202-207.

Danilina, E.I., Mingaleva, Z. A., Malikova, Y.I. 2016. Strategic personnel management within innovational development of companies, Journal of Advanced Research in Law and Economics 7(5): 1004-1013.

Deng, F. 2017. A study on the reform and the design of colleges teaching management system based on innovative personnel training, Revista de la Facultad de Ingenieria 32(8): 256-262.

Foreign prisons. 2011. Peculiarities of architecture, construction, and equipment: analytical overview with offers. - Moscow, Russian Federation: R\&D Institute of the Federal Penitentiary Service of the RF, 92.

García-Ruiz, N., Santiago-Sáez, A., Albarrán-Juan, M.E., Labajo-González, E., Perea-Pérez, B. 2016. Análisis de reclamaciones judiciales contra obstetras y ginecólogos en España. Estudio específico de la vía penal (1987-2013) [Analysis of court claims filed against obstetricians and gynaecologists in Spain. Specific study of the criminal court system (1987-2013)], Revista Espanola de Medicina Legal 42(4): 136-141.

Grushin, F.V. 2017. Crime in the system of factors determining the development of penal policy and legislation, Russian Journal of Criminology, 11(4): 688-695.

Lesting, W. 2018. Die rechtlichen grundlagen der medizinischen versorgung im deutschen strafvollzug [The legal bases of medical care in the German penal system], Medizinrecht 36(2): 69-73.

Luhn, A., Aslanyan, S. Leopoldseder, C. Priess, P. 2017. An evaluation of knowledge management system's components and its financial and non-financial implications, Entrepreneurship and Sustainability Issues 5(2): 315-329. https://doi.org/10.9770/jesi.2017.5.2(11)

Luzgina, A. 2017. Problems of corruption and tax evasion in construction sector in Belarus, Entrepreneurship and Sustainability Issues 5(2): 263-282. https://doi.org/10.9770/jesi.2017.5.2(8)

Mironova, M.D., Zaitseva, N.A., Larionova, A.A., (...), Glagoleva, L.E., Belozerova, J.M. 2017. Features of innovative personnel management of service companies in the period of implementation of organizational changes, Eurasian Journal of Analytical Chemistry 12(5): 793-802.

Rudy, A.A. 2013. Opening speech to the members of the conference from the director of the Federal Penitentiary Service of the RF, Major General of internal service A.A. Rudy. The penal system of the RF in the conditions of modernization: the modern state and perspectives of development: collection of reports of the participants of the International scientific and practical conference: in $4 \mathrm{~V}$. Ryazan: Academy of the Federal Penitentiary Service of the RF, 2013. V. 1: Reports of the plenary session, November 22-23, Ryazan, Russian Federation: Academy of the Federal Penitentiary Service of the RF, P. 192

Seijas, F.V.-P. 2017. La circunstancia atenuante de embriaguez: Una visión de sus elementos y requisitos en algunos sistemas penales iberoamericanos [The attenuating circumstance of drunkenness: A vision of its elements \& requirements in some Ibero-American penal systems], Politica Criminal 12(23): 409-427.

SPS “Consultant Plus" 2017, March 09. The Concept of development of the penal system of the RF until 2020. Adopted by the Decree of the Government of the RF dated October 14, 2010 No. 1772-r. SPS “Consultant Plus”. Retrieved from http://base.garant.ru/1357449

Timofeeva, E. A. 2011. The main tendencies of the process of modernization of higher professional legal education in Russia, Bulletin of Samara Institute of Law: Scientific and Practical Journal, 1(3): 82-86.

Timofeeva, E. A. 2014. Peculiarities of professional training of future employees of the penitentiary system in foreign countries, Bulletin of Samara State Technical University. Series: Psychological and pedagogical sciences 2(22): 192-202. 
Timofeeva, E. A. 2015. Concerning the application of practice-oriented approach in the process of preparation of specialists of the penal system in Samara Institute of Law of the Federal Penitentiary Service of the RF, GYLYM: International Scientific Journal 3(46): 24-29.

Timofeeva, E.A. 2015. Concerning the possibility of integration of foreign experience into the Russian penal system's activities at the modern stage. II International penitentiary forum "Crime, punishment, correction": collection of theses of reports by the participants. V. 1. Materials of the plenary session. Ryazan, Russian Federation: Academy of the Federal Penitentiary Service of the RF, 346-354.

Vodenko, K.V., Ivanchenko, O.S., Shvachkina, L.A., Shilkina, E.L., Rodionova, V.I. 2017. Formation of the national management system in the field of personnel training for modern innovative economy, International Journal of Applied Business and Economic Research, 15(11): 197-205.

Zlakazova, N. 2014. Anatoly Rudy: "The task of the system of departmental professional education is to ensure training of personnel that are capable of performing service duties at the modern stage of development of the penal system". The federal specialized journal "Who is who in education and science"1(11). Retrieved from http://ktovobrnauke.ru/2014/1/anatoliy-rudyy-zadacha-sistemyvedomstvennogo-profobrazovaniya-obespechit-kachestvennuyu-podgotovku-kadrov-sposobnyh-k-vypolneniyu-sluzhebnyh-zadachna-sovremennom-etape-razvitiya-ugolovno-ispolnitelnoy-sistemy.html 